\section{Post-Traumatic C7-T1 Spondyloptosis in a Patient without Neurological Deficit: A Case Report}

\section{Bir Hastada Travma Sonrası Nörolojik Defisit Olmadan Gelisen C7-T1 Spondilopitoz: Olgu Sunumu}

\begin{abstract}
Traumatic cervical spondyloptosis has almost always been associated with disabling neurological deficit and we could only find one case without a neurological deficit reported in the literature. A 42 year old man suffering from severe neck pain following a high speed motor vehicle accident was admitted to our hospital. Magnetic resonance imaging (MRI) and computerized tomography (CT) of the cervical spine and neurologic examination of the patient were performed. The patient was treated with three-column fixation of the traumatic level. We aimed to report a unique case of traumatic C7-T1 total spondyloptosis without a neurological deficit and discuss possible mechanisms and treatment modalities.
\end{abstract}

KEYWORDS: Cervical spondyloptosis, Spinal fusion, Spinal trauma, Neurological deficit

ÖZ

Travmatik servikal spondilopitoz nadir bir patolojidir ve hemen her zaman ağır nörolojik defisit ile birliktedir. Literatürde nörolojik defisiti olmayan sadece bir vaka bulabildik. Yüksek hızlı motorlu taşıt kazasını takiben şiddetli boyun ağrısı şikayeti olan 42 yaşındaki erkek hasta hastanemize kabul edildikten sonra hastanın nörolojik muayenesi yapılarak servikal bölgenin bilgisayarlı tomografisi ve manyetik resonans görüntülemesi yapıldı. Ardından hasta travmaya uğrayan seviyenin üç kolon sabitlemesi yapılarak tedavi edildi. Biz burada nörolojik defisiti olmayan C7-T1 spondilopitozisli bir hastayı sunmayı ve olası mekanizmaları ve tedavi seçeneklerini tartışmak istedik.

ANAHTAR SÖZCÜKLER: Servikal spondilopitoz, Spinal füzyon, Spinal travma, Nörolojik defisit

\section{Cem ACIKBAS ${ }^{1}$ \\ Doga GURKANLAR ${ }^{2}$ \\ 1 Akdeniz University, Faculty of Medicine Neurosurgery Department, Antalya, Turkey \\ 2 Başkent University, Faculty of Medicine, \\ Neurosurgery Department, Ankara, Turkey}

Received : 20.03.2009

Accepted : 16.07.2009

Turkish Neurosurgical Society $20^{\text {th }}$ Scientific Congress, 28.04.2006-02.05.2006, Belek, Antalya, Turkey

Correspondence address: Doga GURKANLAR Baskent University, Alanya Hospital Department of Neurosurgery, 07400, Alanya, Turkey

Phone : +90 5337390549

Fax : +90 2425115563

E-mail : dgurkanlar2000@yahoo.co.uk 


\section{CASE REPORT}

A 42-year-old man who had a high-speed motor vehicle accident was admitted to our hospital.

On admission he was conscious and had no neurological deficit. He was only suffering from intense neck pain.

Plain roentgenograms of the cervical spine failed to show malalignment of the vertebra, but computerized tomography (CT) imaging showed C7-T1 dislocation and C6-C7-T1 laminae and lateral mass fractures. Magnetic resonance imaging (MRI) revealed total spondyloptosis at C7-T1 level with the body of the $\mathrm{C} 7$ vertebra lying almost totally in front of the T1 vertebra without compression of the spinal cord (Figure 1).

The patient was placed on skull traction and serial $x$-ray scans were obtained each day. At the end of the 5th day, correction of the spinal alignment was observed at C7-T1 level. The patient was operated upon in the supine position following fiber optic intubation and with skull traction in place, on the sixth day. The cervical spine was exposed by a standard right sided transverse anterior cervical incision. A C7-T1 discectomy and anterior fusion using a peek cage (Stryker Implants, France) integrated with allograft were performed and a titanium plate (Stryker Implants, France) was inserted. After radiographic examination, we proceeded to suture drainage in situ.

Although cervical alignment was achieved, we performed a posterior surgical approach at another session, three days after the first operation. The patient was operated on in the prone position under general anesthesia and the cervical spine was exposed by cervical midline incision. Posterior stabilization between C4-T3 was performed by C4C5 lateral mass and T2-T3 transpedicular screw fixation and rod constructs due to the lamina and lateral mass fractures at C6, C7, and T1 (Stryker Implants, France). Postoperative MRI and lateral and anterior-posterior $\mathrm{X}$-rays showed the excellent realignment (Figure 2 and Figure 3 A,B).

The postoperative period was uneventful and there were no operation-related complications. Rigid cervical orthosis was used in the postoperative period. The patient was mobilized on the 3rd day, and the postoperative hospitalization was 10 days.
The follow up examination of the patient revealed no neurological deficit.

\section{DISCUSSION}

Shekhar et al described the first spondyloptosis of the cervical spine at C6-7 level with late-onset cord compression, in 1992 (18). The etiology in this case was declared to be post-traumatic, subsequent to a significant birth trauma. Before their case, 10 more similar cases $(2,5)$ with spondylolisthesis and spondylolysis of the cervical spine had been reported in the literature $(5,3,7,14)$ and all were treated either conservatively or by posterior fusion alone.

Traumatic spondylolisthesis of the cervical spine following high-speed motor vehicle accident and diving injuries is relatively common (10), but it is unusual for traumatic spondyloptosis in this region not to be associated with a myelopathy (15).

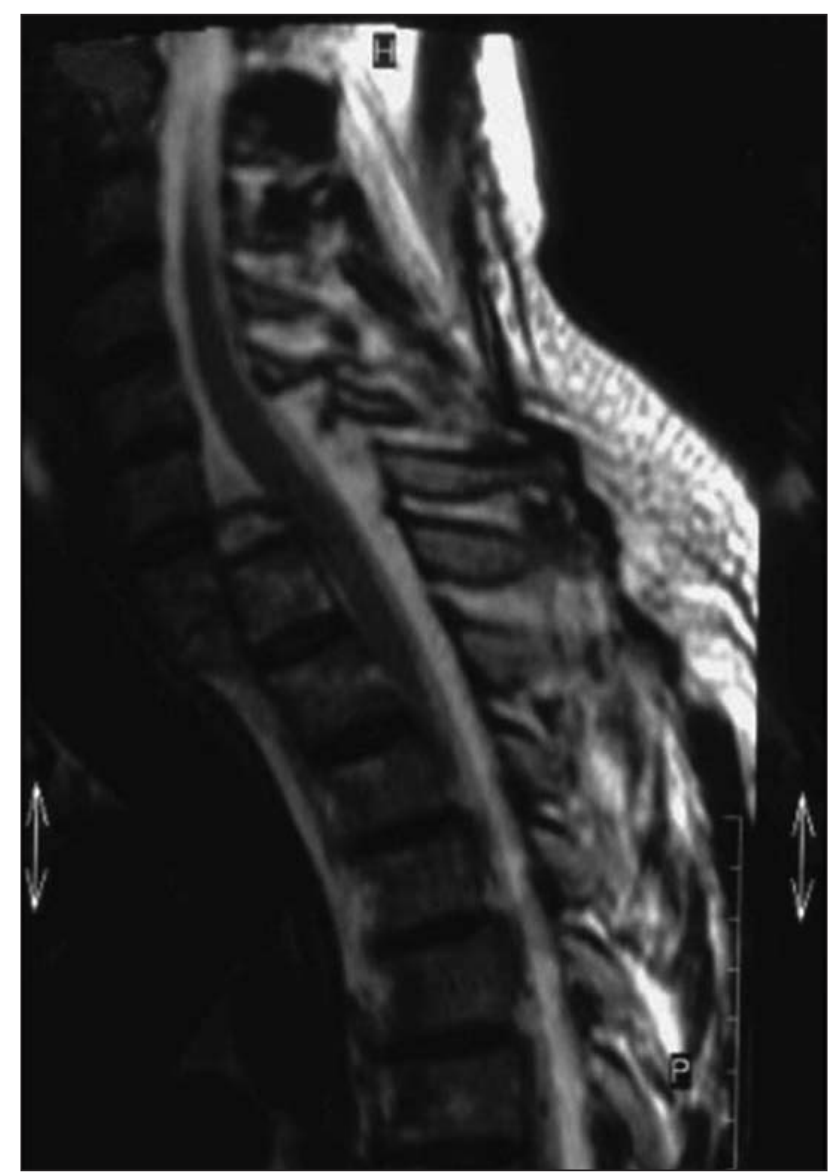

Figure 1: MRI revealed total spondyloptosis at C7-T1 level with the body of the $C 7$ vertebra lying almost totally in front of the T1 vertebra without compression of the spinal cord. 


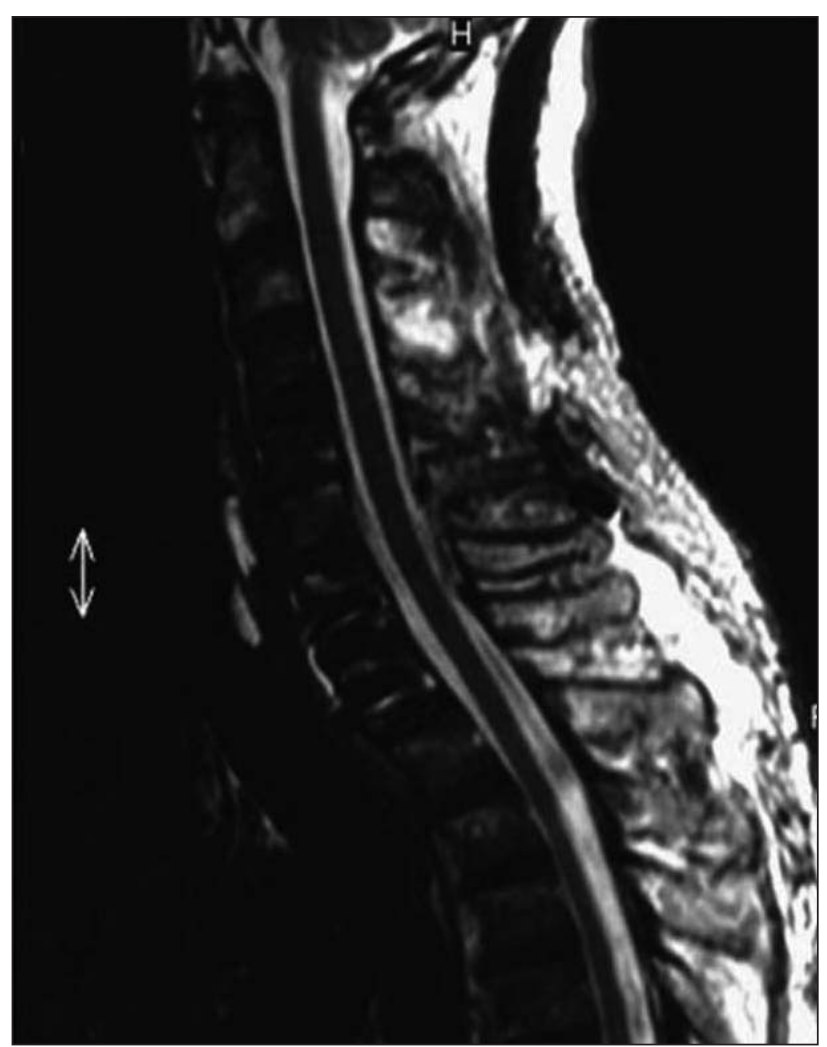

Figure 2: MRI showed successful alignment of the cervicothoracal junction after the operation.

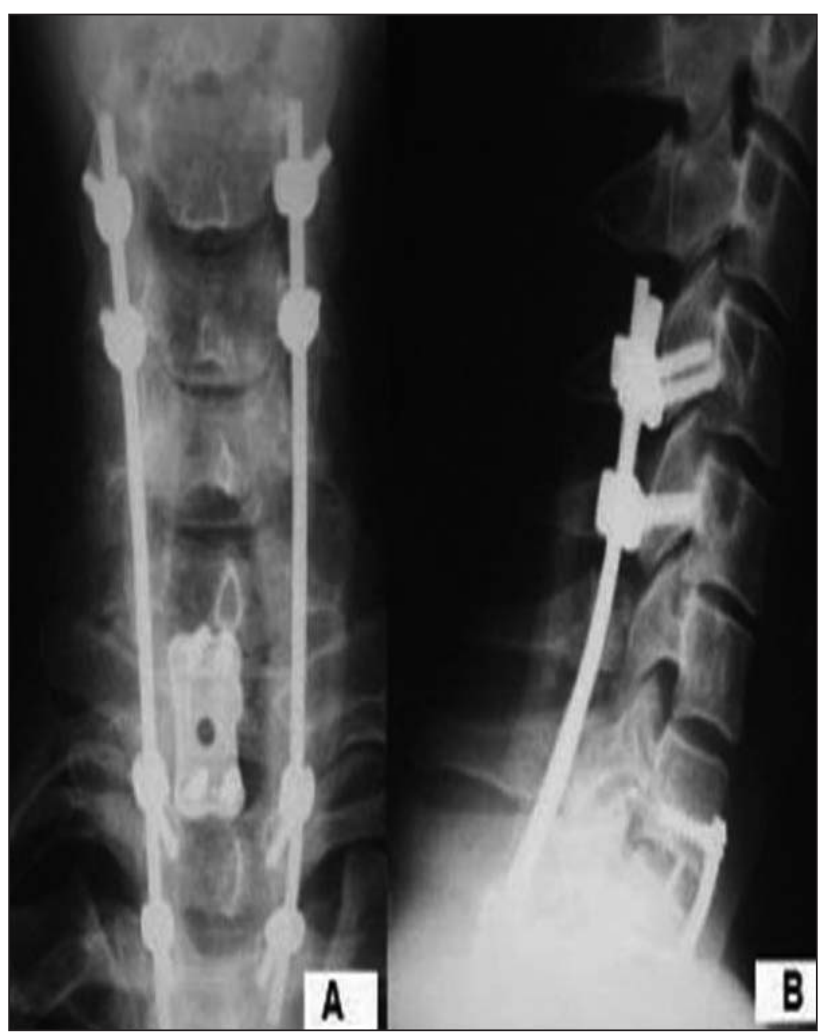

Figure 3: Lateral and anterior-posterior X-rays showed the excellent realignment achieved by C4-C5 lateral mass and T2T3.
Menku and his colleagues were the first to report such a case of (C6-C7 post-traumatic spondyloptosis without neurological deficits) (13). Our case is the first spondyloptosis of the cervicothoracic junction (C7-T1) without a neurological deficit.

We believe that, our patient did not have a neurological deficit due to the posterior element fracture which probably led to a spontaneous dorsal decompression of the spinal canal and allowed the cord to release posteriorly (17).

Most practitioners, as we did in our case, strongly advocate reduction of a case of cervical fracture/instability with no neurological deficit with gradated axial traction applied with the patient awake and under close neurological observation. The axial traction was applied with head tongs in our patient while the intervertebral disc remained in its origin without causing a traumatic herniation and cord compression (6). Traction re-establishes normal spinal alignment and helps initial decompression of the spinal cord (16).

Timing of surgery is under debate. While some authors argue that early operation is associated with significant morbidity due to a retropulsed disc, others believe that early intervention is not associated with a higher incidence of complications $(11,12)$.

In cases of over distraction the weights are reduced to one third of the attempted weight and muscle relaxants, typically diazepam, are administered $(19,21)$

We initially stabilized the fractured level anteriorly to avoid the risk of additional trauma in case of turning the patient on the operation table for the posterior approach. Although an excellent correction of the cervical alignment was achieved by this procedure, we performed a posterior fixation due to the presence of severe laminae fractures at this highly mobile cervicothoracic segment. Thus, we had obtained three-column fusion by means of successful placement of lateral mass and transpedicular screw- rod construction posteriorly and insertion of an anterior cervical plate and peek cage. Therefore, we mobilized and discharged the patient early in the postoperative period.

\section{CONCLUSION}

Although, post-traumatic spondyloptosis without neurological deficit has not been previously 
reported in the literature at C7-T1 level, they should be considered as severely unstable fractures due to both anterior dislocation and multiple posterior element fractures. These patients should be treated with anterior and posterior stabilization techniques in order to achieve early mobilization.

\section{REFERENCES}

1. Akay KM, Ersahin Y, Tabur E: Cervical spondyloptosis: A case report. Minim Invasive Neurosurg 45:169-172, 2002

2. Amacher AL: Cervical spondyloptosis. J Neurosurg 78:853, 1993 (letter)

3. Bellamy R, Liober A, Smith SD: Congenital spondylolisthesis of the sixth cervical vertebra: Case report and description of operative findings. J Bone Joint Surg 56:405-407, 1974

4. Bhojraj SY, Shahane SM: Posttraumatic cervical spondyloptosis at C6-7 with late-onset cord compression: A new clinical entity. Case report. J Neurosurg 177:792-794, 1992

5. Cautilli RA, Joyce MF, Lin PM: Congenital elongation of the pedicles of sixth cervical vertebra in identical twins. J Bone Joint Surg 54:653-656, 1972

6. Chestnut RM, Marshall LF: Early assessment, transport, and management of patients with posttraumatic spinal instability. In: Cooper PR (ed.) Management of posttraumatic spinal instability. Park Ridge 1llinois: American Association of Neurological Surgeons, 1990: 1-17

7. Durbin FC: Spondylolisthesis of the cervical spine. J Bone Joint Surg (Br) 38:734-735, 1956

8. Garneti N, Dunn D, El Gamal E et al: (2003) Cervical spondyloptosis caused by an aneurysmal bone cyst: A case report. Spine 228:68-70, 2003

9. Goffin J, Grob D: Spondyloptosis of the cervical spine in neurofibromatosis. A case report. Spine 24:587-590, 1999
10. Heiden JS, Weiss MH: Cervical spine injuries with and without neurological deficit, part I.Contemp Neurosurg 12: $1-6,1980$

11. Levi L, Wolf A, Rigamonti D et al: Anterior decompression in cervical spine trauma: Does the timing of surgery affect outcome? Neurosurgery 29:216-222, 1991

12. Marshall LF, Knowlton S, Garfin SR, et al: Deterioration following spinal cord injury. A multicenter study. J Neurosurg 66:400-404, 1987

13. Menku A, Kurtsoy A, Tucer B, Oktem IS, Akdemir H: The surgical management of traumatic C6-C7 spondyloptosis in a patient without neurological deficits. Minim Invas Neurosurg 47:242-244, 2004

14. Perlman R, Hawes LE: Cervical spondylolisthesis. J Bone Joint Surg 33:1012-1013, 1951.

15. Riggins RS, Kraus JF: The risk of neurologic damage with fractures of the vertebrae. J Trauma 17:126-133, 1977

16. Section on Disorders of the Spine and Peripheral Nerves of the American Association of Neurological Surgeons and the Congress of Neurological Surgeons: Chapter 6: Initial closed reduction of cervical spine fracture-dislocation injuries. Neurosurgery 50 Supplement (3): Guidelines for the Management of acute cervical spine and spinal cord injuries: 2002: $44-50$

17. Shah KC, Rajshekhar V: Successful management of posttraumatic C7-T1 Spondyloptosis with uninstrumented ventral surgery. Surg Neurol 62:431-434, 2004

18. Shekhar YB, Shahane SM: Post-traumatic cervical spondyloptosis at C6-7 with late onset cord compression: A new clinical entity. J Neurosurg 77:792-794, 1992

19. Sonntag VK, Hadley MN: Non-operative management of cervical spine injuries. Clin Neurosurgery 34:630-649, 1988.

20. Wild A, Jager M, Werner A et al: Treatment of congenital spondyloptosis in an 18-month-old patient with a 10-year follow-up. Spine 26:502-505, 2001

21. Wolf AL: Initial management of brain and spinal cord injured patients. Emerg Med Serv 18:35-41, 1989 